UNIVERSIDADE DE SÃO PAULO

INSTITUTO DE PSICOLOGIA

MARIA ELIZABET LAUTERT DE SOUZA

FORMAÇÃO MÉDICA E HUMANIZAÇÃO

São Paulo

2018 
MARIA ELIZABET LAUTERT DE SOUZA

\title{
FORMAÇÃO MÉDICA E HUMANIZAÇÃO
}

(Versão original)

\begin{abstract}
Relatório apresentado ao Instituto de Psicologia para defesa da tese de doutorado. Área de concentração: Psicologia Escolar e do Desenvolvimento Humano. Orientadora: Professora Doutora Eda Marconi Custódio.
\end{abstract}

\section{SÃo PAULO}




\section{Formação Médica e Humanização}

\section{MARIA ELIZABET LAUTERT DE SOUZA}

Tese submetida ao Instituto de Psicologia da Universidade de São Paulo, para a obtenção do título de Doutora em Psicologia.

Aprovada em

Banca Examinadora

Prof $^{\mathrm{a}}$. Dr ${ }^{\mathrm{a}}$. Eda Marconi Custódio - Orientadoras - IPUSP

Profa. Dra. Maria Julia Kovacks - IPUSP

Prof ${ }^{\mathrm{a}}$. Dr ${ }^{\mathrm{a}}$. Maria Luisa Sandoval Schmidt - IPUSP

Prof. Dr. Reinaldo Ayer de Oliveira - FMUSP

Prof ${ }^{\mathrm{a}}$. Dr ${ }^{\mathrm{a}}$. Rosemary Roggero - Uninove 


\section{AGRADECIMENTO}

Agradeço à Universidade de São Paulo e ao Instituto de Psicologia pela experiência enriquecedora de contato com o mundo acadêmico e científico.

Aos professores e estudantes de Medicina que tornaram possível esta pesquisa, com suas histórias, alegrias, sofrimentos e conhecimento compartilhados comigo.

À minha orientadora, Prof ${ }^{a}$. Drª . Eda Marconi Custódio, por toda a sua dedicação, pela forma carinhosa de dar a direção, por sua generosidade em dedicar seu tempo, demonstrar confiança e sempre incentivar, acreditando inclusive nos momentos mais difíceis, e por sua habilidade em compartilhar seus conhecimentos, respeitando o ritmo e a habilidade de cada um de seus orientandos.

À Olivia, à Sandra e ao Ari que me orientarem nos passos necessários.

Às professoras Malu e Rose pela acolhida ao projeto, pelo aprendizado e pelo espírito de contribuição, gratidão.

À minha filha Karen, pelo incentivo constante, por seu bom humor, pela alegria, pelo carinho, pela compreensão das minhas ausências e por todo apoio incondicional e amoroso.

Ao meu filho Rodrigo, por seu carinho, incentivo e torcida firme e amorosa.

À minha nora Márcia, por seu carinho incondicional e torcida.

Ao meu filho Ricardo por sua alegria.

Aos meus netos Sabrina e Rafael por seu companheirismo, carinho, bom humor, boa disposição e alegria contagiantes, e compreensão da minha falta de tempo e atenção.

Aos meus netos Tamires e Gabriel, por serem tão gentis e queridos, o que aquece o coração.

As minhas queridas colegas e amigas que me incentivaram a continuar e aos queridos colegas pelo encorajamento. 
"O respeito à autonomia e à dignidade de cada um é um imperativo ético e não um favor que podemos ou não conceder uns aos outros."

Paulo Freire (1996) 


\section{RESUMO}

SOUZA, Maria Elizabet Lautert de. Formação médica e humanização. 2018. 160f. Tese de Doutorado, Psicologia Escolar e de Desenvolvimento Humano - Instituto de Psicologia, Universidade de São Paulo, São Paulo, 2018. ${ }^{1}$

A formação médica e a humanização da Medicina tem sido tema de atenção crescente nas áreas da Educação e da Saúde brasileiras. Esta pesquisa teve por objetivo analisar e discutir a formação em Medicina quanto a aspectos relacionados com a visão humanista e humanizada da profissão, bem como as influências da cultura médica e dos sujeitos envolvidos no processo de formação técnica e humanística. Considerou-se que professores e estudantes fazem parte de um contexto social e cultural em que se dá a graduação, a prática médica e a formação, tanto pessoal quanto profissional. Os participantes convidados foram quatro professores e quatro estudantes de Medicina. Foi utilizada a História Oral como método de entrevista, com uma questão inicial disparadora. As narrativas indicaram núcleos temáticos com estreita relação com os objetivos desta pesquisa. Os recortes nas narrativas, destacados nos resultados, foram analisados com fundamentos teóricos relacionados à formação médica e humanização, à luz da Teoria Crítica da Escola de Frankfurt e com contribuições de autores da Sociologia, da Psicologia, da Medicina e da Educação, com os quais fosse possível estabelecer diálogo. Verificou-se um consenso entre os entrevistados - professores e alunos - quanto a ênfase e importância dada à capacitação técnica, sem o que não haveria o exercício adequado da profissão. Reconhecem também a importância das práticas humanizadas na saúde, e o fato de que a humanização deve ser desenvolvida e praticada desde a formação, estendendo-se ao exercício da profissão. No entanto, comentam de diferentes modos a necessidade de uma mudança estrutural, que abarque a cultura médica acadêmica e hospitalar e, de forma mais ampla, o sistema de saúde imerso na cultura da sociedade brasileira.

Palavras-chave: Formação médica. Humanização. Educação Médica. Humanidades na Medicina.

\footnotetext{
${ }^{1}$ Importante destacar que esta pesquisa não tem o propósito e nem a finalidade de gerar conflito de interesse.
} 


\begin{abstract}
SOUZA, Maria Elizabet Lautert de. Medical education and humanization, 2018. Thesis (PhD in School Psychology and Human Development) - Institute of Psychology, University of São Paulo, São Paulo, 2018. ${ }^{2}$
\end{abstract}

The medical education and humanization of Medicine has been a topic of growing attention in the areas of Brazilian Education and Health. The aim of this research was to analyze and discuss medical education regarding aspects related to the humanistic and humanized view of the profession, as well as the influences of the medical culture and the individuals involved in the process of technical and humanistic education. It was considered that teachers and students are part of a social and cultural context in which the graduation, medical practice and education are provided, both in personal and professional field. The invited attendees were four teachers and four medical students. Oral History was used as an interview method, with an initial triggering question. The narratives indicated thematic nuclei closely related to the aims of this research. The narrative clippings, highlighted in the results, were analyzed with theoretical foundations related to medical education and humanization, in the light of the Critical Theory of the Frankfurt School and with contribution from Sociology, Psychology, Medicine and Education authors, with whom dialogue was possible. There was a consensus among the interviewees - teachers and students - regarding the emphasis and importance given to technical training, without which there would be no adequate exercise of the profession. Furthermore, they recognize the importance of humanized practices in health, and the fact that humanization must be developed and practiced since the education, extending to the exercise of the profession. However, in different ways, the necessity of a structure change which embraces the medical, academic and hospital culture and, more broadly, the health system immerse in the Brazilian society culture was remarked.

Key words: Medical Education. Oral History. Humanization. Health.

\footnotetext{
${ }^{2}$ It is substantial to highlight that this research does not have the purpose or the goal of generating conflict of interest.
} 


\section{LISTA DE SIGLAS}

$11^{\text {a }} \mathrm{CNS}-11^{\mathrm{a}}$ Conferência Nacional de Saúde

Abem - Associação Brasileira de Educação Médica

CAAE - Certificado de Apresentação para Apreciação Ética

Caem/Abem - Comissão de Avaliação das Escolas Médicas da Associação Brasileira de

Educação Médica

CNE - Conselho Nacional de Educação

CNS - Conselho Nacional de Saúde

Cobem - Congresso Brasileiro de Educação Médica

Cremesp - Conselho Regional de Medicina do Estado de São Paulo

DCN - Diretrizes Curriculares Nacionais

Fies - Fundo de Financiamento Estudantil

FURG - Universidade Federal de Rio Grande

MCCP - Método Clínico Centrado na Pessoa

Maea - Metodologias Ativas de Ensino e Aprendizagem

MEC - Ministério da Educação e Cultura

PNH - Política Nacional de Humanização

Prouni - Programa Universidade para Todos

UBS - Unidade Básica de Saúde

UFRN - Universidade Federal de Rio Grande do Norte

USP - Universidade de São Paulo

SUS - Sistema Único de Saúde

TCLE - Termo de Consentimento Livre e Esclarecido 


\section{SUMÁRIO}

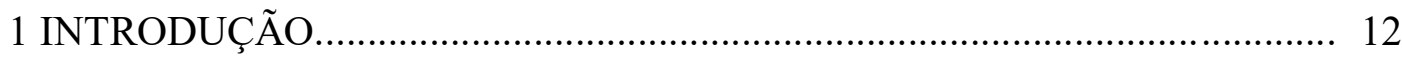

1.1 Formação e humanização................................................................. 15

1.2 Medicina: história e formação médica ................................................ 22

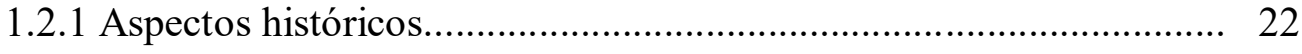

1.2.2 Criação das Escolas Médicas.............................................................. 29

1.2.3 Medicina Liberal e Saúde: o espaço social e profissional do médico na virada do século XX............................................................ 38

1.2.4 Medicina e espaço do médico no século XX e XXI.......................... 42

1.2.5 Educação Médica.......................................................................... 44

1.2.6. Medicina centrada na pessoa...................................................... 47

1.3 Sujeito, cultura, sociedade, formação e trabalho..................................... 48

1.3.1 A pessoa que escolhe................................................................. 49

1.3.2 Cultura e sociedade.................................................................... 55

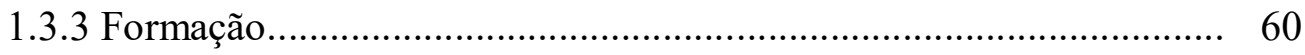

1.3.4 Profissão, carreira, trabalho.......................................................... 65

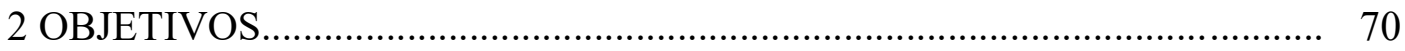

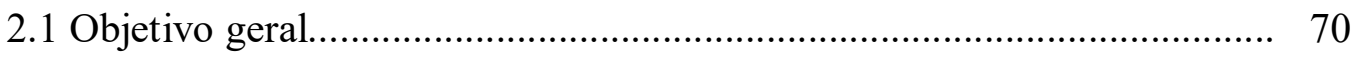

2.2 Objetivos secundários..................................................................... 70

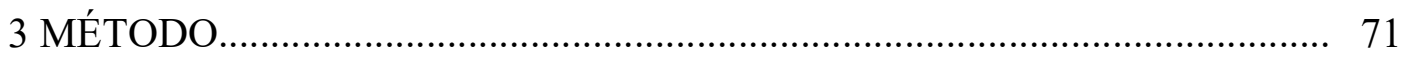

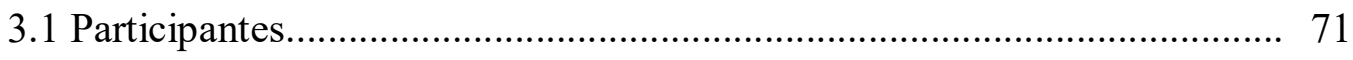

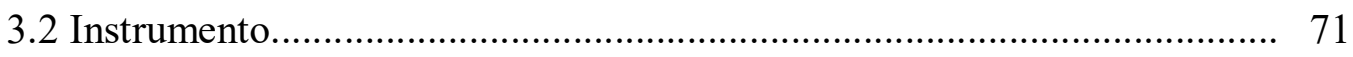

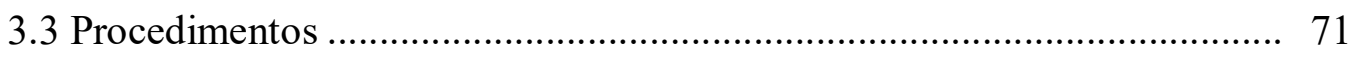

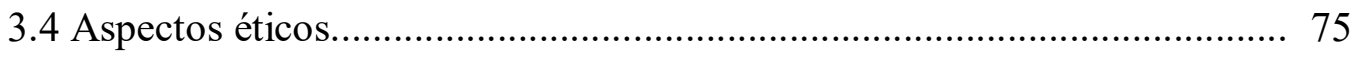

4 RESULTADOS E DISCUSSÃO............................................................ 76

4.1 Escolha da Medicina...................................................................... 78

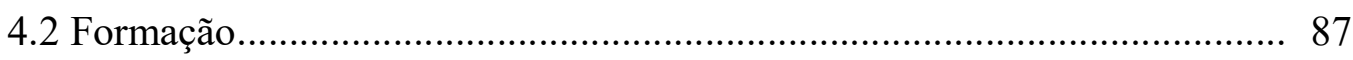

4.2.1 Formação: o que mudou durante o curso....................................... 91 
4.2.2 Formação - perfil do aluno........................................................... 98

4.2.3 Formação: Estágios - Internato...................................................... 106

4.2.4 Formação - relação médico-paciente............................................... 113

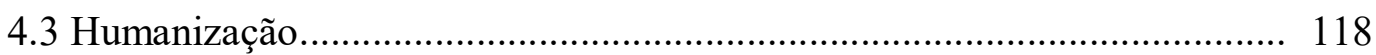

4.3.1 Humanização - modelo do professor............................................ 120

4.4 Trabalho - a Medicina é um trabalho ................................................... 132

4.4.1 Preparação para o trabalho.......................................................... 136

5 CONSIDERAÇÕES FINAIS............................................................. 143

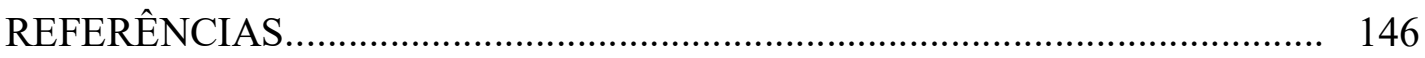

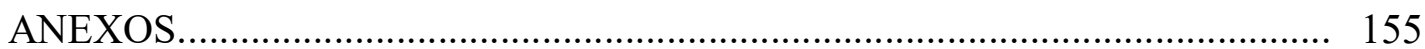

